\title{
Coordinating Information and Controlling Costs
}

Chapter prepared for The Cornell School of Hotel Administration on Hospitality: Cutting Edge

Thinking and Practice, Eds. Michael C. Sturman, Jack B. Corgel,\& Rohit Verma

Gordon Potter

Cornell University

I want to cover two essential and related topics in this chapter: determining the extent of decision rights you grant to your employees, and the management reports you provide to these employees to motivate them to effectively utilize resources. I recognize that if you are a sole practitioner, you may handle these all on your own. But if you hire people to manage your property, you should consider the points I discuss here.

\section{Assigning Organizational Units Financial Responsibility}

As an owner or operator of a hospitality enterprise, one of your primary objectives is to maximize the value of your organization. To meet this objective, one of the most important resources you will need to develop and motivate is a highly competent property-level management team. Most hospitality firms motivate, control, and evaluate the behavior of their property managers and other key property employees using performance measurement systems. From an owner's perspective, the issue becomes the degree of responsibility and the type of measurable results that you assign to your property-level managers.

Depending on the size of your organization, you need to determine whether decision making should be centralized at your headquarters or decentralized and given to your property 
managers. Then, once you have assigned a set of decision rights to key property personnel, you need to determine how you will motivate and measure their performance. Assuming that you are not a sole proprietor or a hands-on manager (and even if you are), this chapter discusses the factors that determine the extent of decision-making authority you might want to give to property-level employees. After we discuss management decision making, we illustrate how you can design property- level financial reports to motivate your property-level employees to focus on the dimensions of performance you wish them to attend to. The better you can link your property-level manager's responsibilities to their measured performance, the more likely it is that your organization will succeed in meeting its objectives.

\section{Location of Decision Rights}

Your first consideration is how much decision authority you will give to your property managers. The degree of accountability that you will expect evolves from your decision about property managers' responsibilities. Although it might be hard for you to give up direct control, let's look at the many benefits you might realize by having a decentralized firm where you allow property- level general managers and their subordinates to make most of the operating decisions (based on your overall strategy and principles). These benefits may include quick response time to customer requests and unforeseen events, the ability to obtain and use local information, and an empowered workforce whose commitment is escalated because they are given substantial responsibilities. Additional benefits you may realize from decentralization include the conservation of your headquarters' resources (or your own personal time and energy) and the development of future corporate managers. 
To the contrary, you probably are thinking of arguments for you to retain decision rights, or to be more centralized. These include the ability to transfer knowledge throughout the organization and therefore adopt best practices, specialization of your workforce, and the benefits that come from economies of scale. An additional benefit for lodging companies with multiple units within a market is the coordination of marketing activities and information for pricing policies. This last point is important, because it has long been recognized that highly decentralized units in the same company can unintentionally compete with each other. For large branded hospitality firms, the push for centralization also comes from the need for a uniform and consistently high-quality product across operating units.

\section{Financial Performance Measures}

If you have decided to decentralize your management operations, you will need to develop a well-defined set of responsibilities for managers operating at the property level. The results from these responsibilities are generally measured in financial terms based on a financial control system that is, in turn, based on the decision rights you have given to your unit-level managers. Financial control systems, sometimes referred to as financial performance measurement systems, are used for many reasons. Perhaps the most important reason is that profit-seeking organizations expressly state many of their objectives in financial terms. For instance, you may have an explicit goal to maximize the profit or value of each property that you own. Financial measures are also needed to ensure that your organization remains solvent, and in many instances these measures are the basis for distributing the cash flows from your enterprise among the various claimants. Financial numbers also provide a good summary of the overall achievements of the business unit and are reasonably precise and objective. Finally, because 
lenders and taxing authorities require financial information, developing additional financial information for managers should be relatively costless for your organization.

Although financial measures have drawbacks, virtually all hospitality organizations use control systems based on financial performance measures. Specific concerns with financial measures include that they can be manipulated by managers; they address only past performance; many workers don't know how to influence financial measures, and financial measures may discourage investment because of the time lag between current investment and the future income from the investment.

Consequently, many performance measurement systems also incorporate nonfinancial measures to ensure that managers are focused on the future, have contracting alternatives, and to provide guidance for frontline personnel who have little effect on financial numbers. However, nonfinancial measures also have drawbacks. Workers may lose sight of the enterprise's goal of ensuring future cash flows and value creation. Additionally, not all nonfinancial measures suggest the same action, little is known about the true cost of obtaining high scores on a particular measure, nonfinancial measures are costly to obtain, and in some instances, they are manipulated. Despite these factors, designing performance measurement systems with nonfinancials can lead to improved financial performance. ${ }^{1}$

Since the use of financial measures seems unavoidable, let's consider the responsibility center you should design for your property managers. As an owner, you should consider designing financial responsibility centers that align the incentives of employees with those of your organization. If you are a manager, you certainly want to be assigned financial responsibility only for financial numbers that you can control. That said, as an owner, you may wish to assign certain financial goals to managers that you want them to attend to even if the 
goals are not controllable by these managers. In lodging companies, for instance, many propertylevel general managers are evaluated on gross operating profit (GOP), which is a reported profit number before management fees and fixed charges for property tax and insurance. However, if you want general managers to take actions that might, however slightly, drive some other cost, such as property taxes or insurance costs, you might hold general managers accountable for net operating income (NOI) or earnings before interest, taxes, depreciation, and amortization (ebitda).

You sometimes see alternative financial performance measurement systems that can inform you about the actions of the managers. For example, you or your staff might compare the manager's financial performance to that of a group of comparable hotels, which is called relative performance evaluation. In this instance, even though the manager cannot control the performance of the other hotels, a comparison of her performance to a set of similar properties may help your assessment of the manager's ability and effort, by controlling for the uncertain economic environment. Finally, because the payment of managerial rewards requires cash flows, the manager's performance may be assessed more on the property's ability to pay off its obligations than on the items that are controllable by the manager. For instance, proxy statements of Marriott and Starwood revealed that Starwood, but not Marriott, required that EBITDA reach a certain threshold before any bonus was paid to top executives.

From the agency perspective, good attributes of measures include the precision with which the measures reflect your employee's activities and the extent to which the measures motivate actions that are consistent (congruent) with your organizations' goals. GOP is a typical measure for property-level managers, so that's the one we'll discuss going forward. 


\section{Types of Responsibility Centers}

Although hotel managers generally are responsible for profits, let's look at four types of responsibility centers, as shown in Table 28.1. In a cost center, your manager's focus is on controlling costs, and performance is controlled and evaluated by comparing actual costs incurred to standard or budgeted costs allowed, given the actual output (actual rooms sold). Examples of cost centers at lodging properties might include maintenance, housekeeping, and human resource departments. ${ }^{2}$ In a revenue center, your managers' focus is on generating revenue without consideration of costs, with the possible exception of certain minor direct costs. Examples include the room reservation department or banquet sales. A revenue center's performance report compares actual sales with budgeted sales. In a profit center, your managers must consider both revenues and costs, and their performance compares actual profit to budgeted profit. Hotel profit centers typically include rooms and food and beverage divisions. Managers of an investment center have responsibility for investment, as well as revenues and costs. Managers are often evaluated by comparing return on investment (ROI) or other profit measure to a budgeted amount. While an owner's analyses of a property's economic viability will generally be from an ROI perspective, it is rare that you would evaluate your general managers at the property level as if they operated as an investment center.

\section{Choosing a Type of Responsibility Center}

From the owner's perspective, an important issue is whether to assign financial responsibility to your property-level managers, and if so, how much? By following the Uniform System of Accounts for the Lodging Industry (USALI), you will have available a well-defined uniform financial report on property-level operations. ${ }^{3}$ In a survey of USALI use, 78 percent of 
the respondents stated their property used the system, primarily due to corporate demands. Moreover, many studies reported that lodging organizations all reported using budgetary amounts as the main performance indicator, or as one of the few key indicators, when evaluating the property-level management team. ${ }^{4}$

Your choice of financial responsibility center depends on your goals and managers' ability to influence the performance measure. For example, property- level managers have little to no control over the initial financial investment in the property and may only have minor influence over new capital investment. Thus, it is unlikely that you would evaluate your property-level managers based on investment center measurements. It would, however, be possible for you to include certain measures that the managers do influence, such as inventory turnover (or the total inventory amount), accounts receivable turnover, total working capital measures, or perhaps capital expenditure amounts to ensure that managers attend to some aspects of costly investment. It also seems inappropriate that you would judge property managers on a revenue center model. There is no question that property-level managers are seeking to drive revenue, but they also need to ensure that the necessary resources are available and that the appropriate activities are being undertaken to provide a high-quality product or service according to your organization's expectations.

\section{Profit Center versus Cost Center}

Let's compare profit center and cost center reporting. The choice hinges on how much you and your corporate staff want property-level managers to focus on revenues and how much control you believe managers have on revenue outcomes. There are clear benefits to having your property-level management team focus on revenues. For one, revenue may be a proxy for the 
quality of the service at the hotel, as high-quality service should generate increased demand and a price premium. Thus, having the manager focus on revenues may drive her efforts on guest service. This rationale also argues against your choosing a cost center responsibility system. Important as it is to control costs, focusing solely on costs runs the risk of cutting back on resources too much, at the cost of quality. If managers are responsible for profit center reporting, they are also more likely to find new customers or sources of business in the local community and seek other ways to increase net revenues.

Despite the potential pitfalls of cost center performance measurement, you still might want to consider measuring your manager against a cost center report. To begin with, many of the benefits that come from focusing on revenues can be obtained using alternative performance measures, as I mentioned earlier. For instance, customer expectations and service quality can be directly measured using nonfinancial performance measures such as customer satisfaction, customer complaints, quality metrics, and property-level audit reports. You can also obtain measures of new customers and new product growth, as well as employee measures. While the collection of this information is costly, many organizations already accumulate this information for other purposes.

Although managers seek to drive revenue, in many instances they often have little control over rates and revenues. In restaurant chains, for instance, managers have little control over prices, and those with a large transient business also have little control over demand. In the lodging industry, central reservation systems and overall brand image can have significant influence over revenues, leaving little rate leeway for general managers. In addition, changes in economic circumstance, such as 9/11, volcanic and flu activity, and deep economic downturns like the recent severe recession, limit the unit-level manager's ability to influence revenues. In 
these instances, property-level employees have much more control over costs than they do over revenues. Thus, operating as a cost center induces the manager to focus activities on dimensions where they can truly make a difference even in the face of a huge economic downturn.

As you have seen from this discussion, the issues of decision rights and financial control systems are not necessarily cut and dried. While every owner desires a fair financial return on each property, and properties must yield positive cash flows to remain viable, there may be added benefits to your organization by designing appropriate responsibility centers and rewarding property-level managers according to the financial factors that they can control effectively.

Few hospitality organizations provide information on their performance measurement systems. Those that do typically provide profit center performance reports for their properties. Denton and White describe the design and implementation of a performance measurement system for a company that operated 38 limited service properties. ${ }^{5}$ The performance measurement system included one measure for each dimension of the balanced scorecard. The company also used a flow-through measure of profitability that compares actual profit to expected profit given actual output (rooms sold). As such, this latter measure focuses on cost control and thus the performance measurement system provides an example of a form of cost center supplemented with nonfinancial measures.

\section{Measuring your Manager's Financial Contribution}

Numerous studies have reported that all properties use financial amounts as a part of their performance measurement system. Studies have also revealed that these financial budgets are not adjusted for changes in economic circumstances during a period. That is, lodging organizations 
do not use flexible budgets. For instance, surveys of the budgeting practices of small hotel companies found that the primary perceived benefits of budgets concerned coordination and control issues. Several studies have confirmed that even though budgets suffered from a lack of accuracy that was related to the impact of economic events, virtually no firms used flexible budgeting techniques for performance evaluation. Thus, budgets remained constant over the

reporting period; hotels did not adjust budgets during the period as conditions warranted. ${ }^{6}$ These studies suggest, therefore, that property-level managers' overall performance, as measured against budget, is highly dependent on the economic environment and that any changes in economic conditions will have a large impact on measured performance.

\section{Typical Performance Report}

A depiction of a simplified financial performance report for a limited-service hotel is presented in Table 28.2, ignoring income other than room revenues. Other income is typically a small portion of income for limited-service hotels. Although my example is a limited-service hotel, this model can be extended to a full-service hotel and to a restaurant by assuming a constant product mix. If your manager is held accountable for profit variances from budget, your performance measurement system requires a profit center report similar to the one in the table. Note that the statement stops at the GOP (gross operating profit) line, and therefore the statement does not provide for any management fees and fixed charges that may include insurance, rents, and property taxes. As I said earlier, GOP is a typical number for assessing a general manager's performance. The report reveals that for the period, the property missed its budgeted GOP by $\$ 141,823$. A review of sales activity also demonstrates that actual average daily rate (ADR) and occupancy were below budget. The report reflects the key aspects of financial reporting of most 
hotels, as properties tend to operate as profit centers and compare actual results to beginning-ofthe-period budgeted amounts.

This report doesn't really tell you how the general manager and other property-level employees managed costly activities and resources in response to the unforeseen changes in demand. For this, you might look at expense per occupied room or expense as a percentage of revenue. These calculations are useful, but an underlying assumption with these metrics is that all operating costs are variable. Alternatively, using a measure such as expense per available room treats the expense per available room as completely fixed. Either way, the performance report doesn't provide the information to ascertain how well the management team has controlled costs in response to a drop in demand. A useful way for you to examine this is by means of a flexible budget that provides for a benchmark cost for any level of activity. Flexible budgets help motivate managers to adapt cost effective strategies as conditions change. These types of budget provide clear benchmarks for identifying and explaining cost variances.

\section{Building a Cost Model}

To create a flexible budget your organization needs to estimate how costs will behave with changes in output, in this case, rooms sold. Although lodging companies have some sense of the variable cost of a room-night for their properties, the accuracy of the estimate is ascertained only after the model estimates have been compared to actual realizations. Thus, the largest drawback to constructing a flexible budget is the potential error in cost modeling. A simple approach that your organization could use to estimate a property's fixed and variable costs is through detailed account analysis. For instance, Table 28.3 depicts how a manager could estimate the fixed and variable portions of the rooms department expense. In account analysis, 
the manager examines each line item, reads any contract related to the costly resource, and classifies each cost as fixed, variable, or mixed, if it includes both fixed and variable components.

In our example in Table 28.3 you begin by examining payroll records and classifying employee pay as salary (fixed) or wages (variable). Payroll- related expenses are apportioned by employee type. The other key expenses, such as laundry, linens, supplies, commissions, and complimentary food are assigned as a variable cost. Finally, other is apportioned equally. Obviously, more detailed analysis would be necessary, as there are numerous costs in each summary expense category. Summing up the amounts in our example, the rooms department is estimated to have annual fixed costs of $\$ 166,000$ and a variable cost per room-night of $\$ 13.20$.

The cost behavior of the other expenses at the property is provided in Table 28.4. The table reveals the fixed and variable costs for each expense item. It also demonstrates that the annual estimated fixed expenses are $\$ 421,000$, and the variable cost per room-night is $\$ 27.05$. Clearly, your estimates are going to be measured with error, but your intuition is the best way to begin the modeling of costs. Eventually, you might want to use more heavy-duty statistical techniques, such as linear regression. Although it's not perfect, regression is quick, uses all data points, and uses a well-defined criterion. A good cost model will be intuitively plausible, will have been tested on data, will fit the data, and will do a good job predicting future observations. Moreover, it will be in need of constant refinement and will need to be altered to meet the needs of the organization. During the last deep recession, for instance, your organization might have had the incentive to treat as many costs as possible as variable costs to induce managers to cut back on resource use in the face of the drop in business. While cost estimation is difficult, it 
should be an integral part of your budgeting process, and therefore it should be available for performance evaluation.

\section{Flexible Budget Report}

Let's look at the flexible budget report, as shown in Table 28.5. The total profit variance is the same as that reported in Table 28.2, \$-141,823, but the report in Table 28.5 provides a flexible budget column that represents what the revised budget would have been once the actual number of room-nights is known. Thus, the flexible budget uses the actual room-nights sold, 28,251 , to create a column that represents what budgeted performance would be if the actual number of rooms sold were known at the time the budget was produced. The flexible budget reveals that your property under review should have earned a gross operating profit of $\$ 1,216,145$, as compared to the original budget profit forecast of $\$ 1,304,983$. This profit difference is related to the change in quantity of rooms sold, 28,251 actual rooms sold versus 29,784 planned rooms sold. This profit volume variance of $\$-88,838(=\$ 1,216,145-$ $\$ 1,304,983)$ is equal to the drop quantity of rooms $-1,533(=28,251-29,784)$ times the lost contribution per room. In this case, the estimated lost contribution per room is the ADR minus the variable cost, or $\$ 57.95$ (= $\$ 85.00$ - $\$ 27.05)$. Therefore, the profit lost is $\$ 57.95 \times 1,533$ rooms $=\$ 88,838$. Some practitioners compute a flow-through percentage, which is the percent of each extra dollar of revenue that should result in profit. This is the contribution margin divided by revenues, or on a per-unit basis, contribution per unit divided by price. In this instance, it is $\$ 57.95 / \$ 85.00$ or about 68.18 percent. This is also called the contribution margin ratio. 
The profit volume variance that we just calculated is due to changes in occupancy, which you may determine the general manager at the property has little control over. The flexible budget also isolates the impact of ADR changes on revenues. This can be ascertained by examining the difference between actual room revenue, $\$ 2,370,000$, and room revenue under the flexible budget, $\$ 2,401,335$. This amount is the ADR rate differential, which is $\$-1.11$ times the quantity of rooms sold (rate differential calculated as $\$-1.11=\$ 83.89-\$ 85.00$ ). Thus, this variance is $\$-31,335(=\$-1.11 \times 28,251$ rooms, with rounding).

What is most important is the examination of your property's operating costs, which can be seen by comparing actual costs to costs allowed, given the actual output of the flexible budget, as shown in Table 28.6. With the exception of marketing, all of the expenses in Table 28.6 are over the amounts allowed by the flexible budget. Assuming the cost modeling is correct, this suggests that the managers at the property did not reduce costs sufficiently in response to the drop in demand. Note that actual costs are $\$ 1,206,840$ and budgeted costs allowed given actual room-nights sold are $\$ 1,185,190$. Thus, there were cost overruns of $\$ 21,650$. Compare this to the analysis of the typical profit center report presented in Table 28.2. In that table, the cost variances are all favorable, in the sense that costs came in under the original budget, but that was easy to accomplish given the drop in room-nights sold. The flexible budget reveals the cost reductions were insufficient. Therefore, your managers at this property probably did not cut back on inputs as much as they might have, given the drop in rooms sold. The important question is, if the manager's performance had been measured against a flexible budget would she have been more likely to cut back on costly unnecessary resources as room demand dropped? 


\section{Conclusion}

Performance measurement systems are a key method for you to motivate, control, and evaluate your managers. This chapter shows you how to determine how well your organization's performance measurement accomplishes its intended task. In addition to looking at the factors that will help you determine the extent of decision-making authority you are going to give to property-level employees, this chapter has offered some alternative ways to think about designing financial control systems to control operating costs and thereby increase your profits. In general, hospitality organizations align property-level managers' incentives with their organization goals by rewarding these managers for meeting or exceeding budgeted profit. However, in environments like that of the recent deep recession, where there is much demand uncertainty, or in organizations where revenue is generated primarily from corporate activities, it may be better for you to use benchmarks that managers can actually control, or at least isolate different components of performance. In this environment, designing property-level performance measures that more closely monitor costly activities may be beneficial. As such, this chapter has presented alternative performance measurement approaches that may help your property-level employees focus on the aspects of performance they best control and in this manner improve your organization's overall performance. 


\section{Notes}

1. R. D. Banker, G. Potter, and D. Srinivasan, "Association of Nonfinancial Performance Measures with the Financial Performance of a Lodging Chain," Cornell Hotel and Restaurant Administration Quarterly 46(4) (2005): 394 -412.

2. American Hotel and Lodging Association, Uniform System of Accounts for the Lodging Industry, 10th ed. (Washington, DC: American Hotel and Lodging Association, 2006).

3. F. Kwansa, and R. S. Schmidgall, "The Uniform System of Accounts for the Lodging Industry: Its Importance to and Use by the Hotel Managers." Cornell Hotel and Restaurant Administration Quarterly (1999): 40(6): 88 -94.

4. T. A. Jones, "Changes in Hotel Industry Budgetary Practice," International Journal of Contemporary Hospitality Management 20(4) (2008): 428 -444.

5. G. A. Denton and B. White, "Implementing a Balanced-Scorecard Approach to Managing Hotel Operations," Cornell Hotel and Restaurant Administration Quarterly 41(1) (2000): 94-107.

6. J. G. Kosturakis and J. J. Eyster, "Operational Budgeting in Small Hotel Companies," Cornell Hotel and Restaurant Administration Quarterly 19(4) (1979): 80-84; and R. S. Schmidgall, and A. L. DeFranco, "Budgeting and Forecasting: Current Practice in the Lodging Industry," Cornell Hotel and Restaurant Administration Quarterly 39(6) (1998): $45-51$. 
Table 1. Typical Financial Responsibility Centers

\begin{tabular}{lll}
\hline $\begin{array}{l}\text { Type of } \\
\text { Responsibility Center }\end{array}$ & $\begin{array}{l}\text { Manager } \\
\text { Responsibilities }\end{array}$ & $\begin{array}{l}\text { Performance Measurement } \\
\text { Report }\end{array}$ \\
\hline Cost center & Operating costs. & $\begin{array}{l}\text { Actual costs vs. standard cost } \\
\text { allowed. } \\
\text { Actual revenues vs. budgeted } \\
\text { Revenue center }\end{array}$ \\
Operating revenues. & $\begin{array}{l}\text { reves. } \\
\text { Actual profit vs. budgeted } \\
\text { profit. }\end{array}$ \\
Investment center & Operating revenues and costs. & $\begin{array}{l}\text { Actual ROI or economic profit } \\
\text { vs. budgeted ROI or economic } \\
\text { profit }\end{array}$ \\
\hline
\end{tabular}


Table 2. Summary Annual Operating Statement for 120-Room Limited-Service Hotel.

\begin{tabular}{llll}
\hline & \multicolumn{1}{c}{ Actual } & \multicolumn{1}{c}{ Budget } & Variance \\
\hline Room Revenue & $\$ 2,370,000$ & $\$ 2,531,640$ & $(\$ 161,640)$ \\
Room Expense & $(552,120)$ & $(559,149)$ & 7,029 \\
Departmental Income & $1,817,880$ & $1,972,491$ & $(154,611)$ \\
Undistributed Operating & $(225,480)$ & $(227,330)$ & 1,850 \\
Expenses Administrative & & & \\
and General & $(171,480)$ & $(179,028)$ & 7,548 \\
Sales and Marketing & $(122,160)$ & $(122,460)$ & 300 \\
Property Operations and & $(135,600)$ & $(138,690)$ & 3,090 \\
Maintenance & $1,163,160$ & $1,304,983$ & $(141,823)$ \\
Utilities & 83.89 & 85.00 & \\
Gross Operating Profit & $64.50 \%$ & $68.00 \%$ & \\
ADR & 54.11 & 57.80 & \\
Occupancy Rate & 28,251 & 29,784 & \\
REVPAR & 43,800 & 43,800 & \\
Rooms Sold & & & \\
Rooms Available & & & \\
\hline
\end{tabular}


Table 3. Account Analysis Approach to Cost Behavior Estimation: Rooms Department Expense.

\begin{tabular}{|c|c|c|c|}
\hline & $\begin{array}{l}\text { Estimated } \\
\text { Total }\end{array}$ & $\begin{array}{l}\text { Estimated } \\
\text { Fixed }\end{array}$ & $\begin{array}{l}\text { Estimated } \\
\text { Variable }\end{array}$ \\
\hline Salaries and wages & $\$ 307,291$ & $\$ 118,000$ & $\$ 189,291$ \\
\hline $\begin{array}{l}\text { Payroll related } \\
\text { expenses }\end{array}$ & 59,458 & 24,000 & 35,458 \\
\hline $\begin{array}{l}\text { Laundry, linen, and } \\
\text { supplies }\end{array}$ & 55,600 & 0 & 55,600 \\
\hline $\begin{array}{l}\text { Commissions and } \\
\text { reservations }\end{array}$ & 45,800 & 0 & 45,800 \\
\hline Complimentary food & 43,000 & 0 & 43,000 \\
\hline Other & 48,000 & 24,000 & 24,000 \\
\hline Total rooms expense & $\$ 559,149$ & $\$ 166,000$ & $\$ 393,149$ \\
\hline \multicolumn{4}{|c|}{ Estimated variable cost per room night sold — estimated total variable cost/estimated rooms sold } \\
\hline \multicolumn{4}{|c|}{$\$ 393,149 / 29,784$} \\
\hline \multicolumn{4}{|c|}{$\$ 13.20$ per room sold } \\
\hline
\end{tabular}


Table 4. Estimated Fixed and Variable Costs by Expense Item.

\begin{tabular}{lrr}
\hline & Estimated Fixed & \multicolumn{2}{c}{ Estimated Variable per Room } \\
Sold
\end{tabular}


Table 5. Flexible Budget Performance Report of Summary Annual Operating Statement

\begin{tabular}{|c|c|c|c|c|}
\hline & Actual & $\begin{array}{l}\text { Flexible } \\
\text { Budget }\end{array}$ & $\begin{array}{l}\text { Original } \\
\text { Budget }\end{array}$ & Variance \\
\hline Room Revenue & $\$ 2,370,000$ & $\$ 2,401,335$ & $\$ 2,531,604$ & $(\$ 161,640)$ \\
\hline Room Expense & $(552,120)$ & $(538,913)$ & $(559,149)$ & 7,029 \\
\hline Departmental Income & $1,817,880$ & $1,862,422$ & $1,972,491$ & $(154,611)$ \\
\hline $\begin{array}{l}\text { Undistributed Operating } \\
\text { Expenses } \\
\text { Administrative and } \\
\text { General }\end{array}$ & $(225,480)$ & $(222,578)$ & $(227,330)$ & 1,850 \\
\hline Sales and Marketing & $(171,480)$ & $(172,130)$ & $(179,028)$ & 7,548 \\
\hline Property Operations and & $(122,160)$ & $(118,628)$ & $(122,460)$ & 300 \\
\hline $\begin{array}{l}\text { Maintenance } \\
\text { Utilities }\end{array}$ & $\underline{(135,600)}$ & $\underline{(132,941)}$ & $\underline{(138,690)}$ & $\underline{3,090}$ \\
\hline Gross Operating Profit & $1,163,160$ & $1,216,145$ & $1,304,983$ & $(141,823)$ \\
\hline ADR & 83.89 & 85.00 & 85.00 & \\
\hline Occupancy Rate & $64.50 \%$ & $64.50 \%$ & $68.00 \%$ & \\
\hline REVPAR & 54.11 & 54.83 & 57.80 & \\
\hline Rooms Sold & 28,251 & 28,251 & 29,784 & \\
\hline Rooms Available & 43,800 & 43,800 & 43,800 & \\
\hline
\end{tabular}


Table 6. Flexible Budget Cost Center Report from Summary Annual Operating Statement.

\begin{tabular}{lrrr}
\hline & \multicolumn{1}{c}{ Actual } & \multicolumn{1}{c}{ Flexible Budget } & \multicolumn{1}{c}{ Variance } \\
\hline Room Expense & $(\$ 552,120)$ & $(\$ 538,913)$ & $(\$ 13,207)$ \\
Administrative and & $(225,480)$ & $(222,578)$ & $(2,902)$ \\
General & $(171,480)$ & $(172,130)$ & $(3,533)$ \\
Sales and Marketing & $(122,160)$ & $(118,628)$ & $(2,659)$ \\
Property Operations & $(135,600)$ & $(132,941)$ & $(\$ 21,650)$ \\
and Maintenance & $(\$ 1,206,840)$ & $(\$ 1,185,190)$ & \\
Utilities & 83.89 & 85.00 & \\
Total costs & $64.50 \%$ & $64.50 \%$ & \\
ADR & 54.11 & 54.83 & \\
Occupancy rate & & 28,251 & \\
REVPAR & 28,251 & 43,800 & \\
Rooms Sold & 43,800 & & \\
Rooms Available & & & \\
\hline
\end{tabular}

